\title{
Aerotaxis in Halobacterium salinarium is methylation-dependent
}

\author{
Jemima C. Lindbeck, † Eric A. Goulbourne, Jr, $\ddagger$ Mark S. Johnson \\ and Barry L. Taylor
}

Department of Microbiology \& Molecular Genetics, Loma Linda University, Loma Linda, California 92350, USA

\author{
Author for correspondence: B. L. Taylor. Tel: +1909824 4480. Fax: +1 9098244035. \\ e-mail: bltaylor@ccmail.1lu.edu
}

\begin{abstract}
The behavioural response to a gradient of oxygen (aerotaxis) has been characterized in the archaeon, Halobacterium salinarium. When the gas surrounding a drop of $\boldsymbol{H}$. salinarium strain S9-P culture was changed abruptly from $10 \%$ (v/v) $\mathrm{O}_{2}$ to $100 \% \mathrm{~N}_{2}$, the bacteria transiently increased the frequency of reversing before they adapted and resumed random swimming. When the gas was returned to $10 \% \mathrm{O}_{2}$ the bacteria responded by swimming smoothly for approximately $45 \mathrm{~s}$. Aerotaxis was strongest when respiration in $\mathrm{H}$. salinarium was highest and when bacteriorhodopsin and halorhodopsin were not contributing to the proton motive force. Starvation for methionine of the auxotrophic $H$. salinarium essentially abolished the step-down aerotactic response. Methanol production from demethylation of methyl-accepting chemotaxis proteins was transiently increased in $H$. salinarium S9-P by a step down or step up in oxygen concentration, as observed in methylationdependent chemotaxis in $\boldsymbol{H}$. salinarium. The taxis-negative and methyltransferase-deficient mutant, $H$. salinarium strain Pho72 did not exhibit changes in methanol release in response to aerotaxis or chemotaxis stimuli. This is the first report of an aerotactic response that is dependent on methylation of methyl-accepting chemotaxis proteins. Aerotaxis in Escherichia coli and Salmonella typhimurium is independent of transducer methylation.
\end{abstract}

\section{INTRODUCTION}

The archaeon Halobacterium salinarium, formerly known as $H$. balobium, lives in high salt environments. The bacteria are polarly flagellated (Alam \& Oesterhelt, 1984) and change direction by reversing the direction of swimming, unlike the peritrichously flagellated Escherichia coli which changes direction by tumbling (Berg \& Brown, 1972). Aerotaxis, the migratory response toward, or away from, oxygen was first reported in $H$. salinarium when Stoeckenius observed cells accumulating around an air bubble (Stoeckenius et al., 1988). Subsequently, Bibikov \& Skulachev (1989) found that the bands of $H$. salinarium around air bubbles are more intense when the cells are deficient in bacteriorhodopsin and halorhodopsin. Bacteriorhodopsin and halorhodopsin are light-energized

† Present address: Family Practice Residency, Florida Hospital, 2501 North Orange Avenue, Suite 235, Orlando, FL 32804, USA.

¥Present address: The Procter and Gamble Company, Miami Valley Laboratories, PO Box 538707, Cincinnati, OH 45253-8707, USA. electrogenic ion pumps that contribute to the proton motive force in $H$. salinarium and when they are active the cell is less dependent on respiratory proton ejection.

Aerotaxis in Salmonella typhimurium and E. coli requires an electron transport system and is apparently mediated by changes in the proton motive force (Laszlo \& Taylor, 1981; Taylor, 1983; Shioi \& Taylor, 1984; Shioi et al., 1988). Niwano \& Taylor (1982) established that adaptation in aerotaxis in $S$. typhimurium and $E$. coli is independent of methylation of the methyl-accepting chemotaxis proteins in contrast to methylation-dependent adaptation in chemotaxis. (For reviews of chemotaxis in eubacteria, see Bourret et al., 1991 ; Macnab, 1992; Taylor \& Johnson, 1993; McCleary \& Stock, 1993; Armitage, 1993.)

Phototaxis in $H$. salinarium is mediated by specific retinalcontaining photoreceptors, SR-I and SR-II, and does not require changes in the proton motive force (Spudich \& Spudich, 1982). The photochemical reactions of SR-I modulate the HtrI protein which is similar to the methyl- 
accepting chemotaxis proteins (MCP) in eubacteria, but lacks a periplasmic binding domain (Yao \& Spudich, 1992; Spudich \& Spudich, 1993; Krah et al., 1994). Methylation of the HtrI protein appears to be required for normal adaptation in phototaxis. In the absence of SR-I and SR-II, $H$. salinarium cells show a photoresponse that is mediated by bacteriorhodopsin and is dependent on a bacteriorhodopsin-generated change in the proton motive force (Bibikov et al., 1991, 1993; Yan et al., 1992). A set of methyl-accepting taxis proteins in $H$. salinarium that includes the $\mathrm{HtrI}$ protein have apparent molecular masses between $90 \mathrm{kDa}$ and $135 \mathrm{kDa}$ (Spudich et al., 1988; Alam \& Hazelbauer, 1991). Methylation of these proteins increases after positive chemosensory stimuli and decreases after negative stimuli (Alam et al., 1989). Methylation is lacking in several mutants that are defective in taxis and is restored in revertants selected for recovery of taxis (Spudich et al., 1988).

A flow assay (Kehry et al., 1984) that measures the demethylation of the methyl-accepting taxis proteins in vivo has been used to study demethylation in $H$. salinarium cells that have been labelled with $\mathrm{L}-\left[\right.$ metbyl $\left.{ }^{3} \mathrm{H}\right]$ methionine (Spudich et al., 1989; Alam et al., 1989). Both positive and negative chemosensory and photosensory stimuli result in a transient increase in demethylation. The duration of the demethylation response in phototaxis and in chemotaxis approximated to the time for the cells to adapt to the stimuli. This pattern of demethylation is distinct from demethylation in E. coli and S. typhimurium where negative chemosensory stimuli cause a transient increase in demethylation and positive stimuli cause a transient decrease in demethylation (Kehry et al., 1984). The pattern of demethylation exhibited by $H$. salinarium is similar to that observed in Bacillus subtilis (Carpenter et al., 1994). The significance of these differences for the mechanism of adaptation to sensory stimuli is unclear. The present study characterizes aerotaxis in $H$. salinarium and investigates the role of methylation. (A preliminary report of this work has been presented at the 90th General Meeting of the American Society for Microbiology, 1990; Lindbeck et al., 1990.)

\section{METHODS}

Bacterial strains and growth conditions. Halobacterium salinarium S9-P is wild type for chemotaxis and phototaxis (Spudich \& Spudich, 1982); strain Flx15 is deficient in bacteriorhodopsin and halorhodopsin but contains the sensory rhodopsins SR-I and SR-II (Sundberg et al., 1985). Strain Pho81 is a deletion mutant derived from Flx15 that lacks all retinal proteins and the photo-transducing protein HtrI; strain Pho72 is also derived from Flx15 and lacks methyltransferase activity (Spudich et al., 1988). Unless specified otherwise, strains were grown at $37^{\circ} \mathrm{C}$ in peptone medium (Lanyi et al., 1979) in the dark with vigorous agitation. Defined medium was prepared as described by Grey \& Fitt (1976); basal salts buffer was prepared as for peptone medium except for the omission of Oxoid peptone and the inclusion of $10 \mathrm{mM}$ MES, pH 6.8.

Behavioural assays. Temporal aerotaxis assays were performed as previously described (Laszlo \& Taylor, 1981; Shioi et al., 1987 ) in a microchamber that was ventilated with humidified $\mathrm{N}_{2}$ or $10 \%(\mathrm{v} / \mathrm{v}) \mathrm{O}_{2}$ in $\mathrm{N}_{2}$ gas (flow rate $800 \mathrm{ml} \mathrm{min}^{-1}$ ) with the following modifications. A bacterial suspension $(8 \mu \mathrm{l})$ was dispersed on a microscope slide and inserted into the flow chamber where it was ventilated with $10 \% \mathrm{O}_{2}$. After 5-6 min, the ventilating gas was changed to $\mathrm{N}_{2}$ for 1-3 min and then returned to $10 \% \mathrm{O}_{2}$. The $\mathrm{N}_{2}$ gas was passed through an OxiClear gas purifier (Model DGP 250, VWR Scientific) and an indicating Oxy-Trap (Alltech Associates), replacing pyrogallol as the agent to remove residual $\mathrm{O}_{2}$. The bacteria were observed in a dark field microscope and video-recorded using a $\mathrm{COHU}$ (4810 series CCD) camera. Adequate contrast was obtained by use of a $12 \mathrm{~V}, 100 \mathrm{~W}$ halogen light source (Leitz). The entire apparatus, except the video recorder, was placed in a $37^{\circ} \mathrm{C}$ constant temperature room. The water level in the gas-washing bottles that were used to humidify the ventilating gases could be increased or decreased to adjust the humidity of the gas in the microchamber, thereby reducing hydration or dehydration of the bacterial suspension. The volume of the drop of suspended bacteria remained constant for more than $30 \mathrm{~min}$.

The video recording of the free-swimming cells was digitized and analysed by computerized motion analysis (Motion Analysis Corp.) to determine the swimming speed and the reversal frequency of the bacteria (Sundberg et al., 1986; Sager et al., 1988). Expert Vision software (Motion Analysis Corp.) was customized to quantify the motility of $H$. salinarium. The computer program and the rationale for its development has been described (Lindbeck, 1991) and is available from J. C. Lindbeck.

In the spatial assay of aerotaxis, a drop of bacterial suspension (OD ${ }_{600}$ of $0.5-1.0$ ) was placed on a microscopic slide and a cover glass was dropped onto the suspension to trap one or more air bubbles beneath the cover glass. Two thicknesses of paper towel were placed in a Petri dish. Two microscope slides, one on top of the other were placed on the paper towel as spacers. The paper towel was dampened with water, the prepared microscope slide was placed on the two spacer slides and the cover was placed on the Petri dish. After incubation at $37^{\circ} \mathrm{C}$ for $1 \mathrm{~h}$ or more, the distribution of bacteria around the air bubble was examined under the microscope. The sample hydrated in the Petri dish if the paper towel was too wet or dehydrated and crystallized if the towel was too dry.

HPLC studies. HPLC was performed on lyophilized extracts. Seventy-five millilitres of cells grown in peptone medium were washed and resuspended in defined media with or without methionine and with or without the $S$-adenosylmethionine synthesis inhibitors, ethionine or homocysteine. After incubation for 30-60 min, cell extracts were prepared for reversed phase HPLC as described by Johnson \& Taylor (1993). The final volume of the concentrated extract was $500 \mu \mathrm{l}$. Aliquots $(20 \mu \mathrm{l})$ were added to an Alltech Adsorbosphere nucleotide/ nucleoside column. Solvent A contained 0.25 M ammonium acetate, pH 6.0 and solvent $B$ was $100 \%$ methanol. Consecutive stepwise gradients were performed: $0-10 \%$ solvent $\mathrm{B}$ over $20 \mathrm{~min}$ followed by a gradient of $10-20 \%$ solvent $\mathrm{B}$ over the next $10 \mathrm{~min}$ at a flow rate of $1 \mathrm{ml} \mathrm{min}-1$. Absorbance was measured at $254 \mathrm{~nm}$.

Autofluorography of $\left[{ }^{3} \mathrm{H}\right]$ methylated proteins. Cells were labelled with $\mathrm{L}-\left[\right.$ metby $\left.L^{3} \mathrm{H}\right]$ methionine $\left[14 \mu \mathrm{M}, 71 \mathrm{Ci} \mathrm{mmol}^{-1}\right.$ $\left(2.63 \mathrm{~Bq} \mathrm{mmol}^{-1}\right)$; Dupont NEN] essentially as described by Spudich et al. (1988). Where specified, the suspended cells were made anoxic by bubbling with $\mathrm{N}_{2}$ gas. Proteins were analysed by SDS-PAGE using the procedure of Laemmli (1970). Gels were stained with Coomassie blue, destained for $1 \mathrm{~h}$ (Weber \& Osborn, 1969), treated with EN ${ }^{3} \mathrm{HANCE}$ (Dupont NEN) following the manufacturer's protocol and dried under vacuum. The dried gel was analysed by fluorography on $\mathrm{X}$ OMAT AR (5) film (Kodak) that was pre-exposed by electronic 


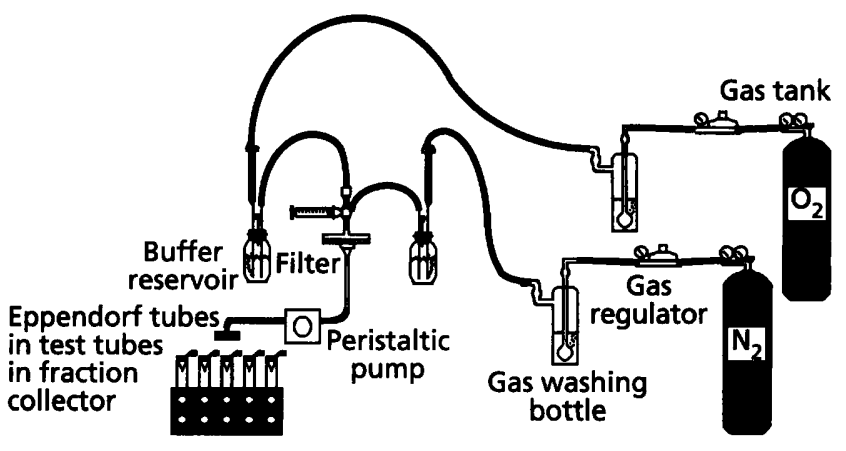

Fig. 1. Diagram of continuous flow apparatus for aerotaxis assay. Bacterial cells were loaded through the syringe port and trapped on the filter. A valve was used to switch from $\mathrm{N}_{2}$ equilibrated perfusion buffer to $\mathrm{O}_{2}$-equilibrated buffer. The perfusate was collected in a fraction collector.

flash. The fluorogram was quantified using the scanning accessory to a DU-8 spectrophotometer (Beckman Instruments). The peaks in the scan were cut out and weighed after enlarging the scan in a photocopier. The label incorporated into each band was expressed as a percentage of the combined label in the seven bands of the region.

Flow assay of demethylation. For the flow assay of methylesterase activity in vivo, the procedure of Kehry et al. (1984) was used, as modified for $H$. salinarium by Alam et al. (1989). The apparatus was further modified for aerotaxis flow assays (Fig. 1). Butyl rubber tubing (outside diam., $11 \mathrm{~mm}$; inside diam., $4.8 \mathrm{~mm}$, Fisher Scientific) that has a very low permeability to oxygen was used between the gas cylinders and the filter. The gas regulators were adjusted to 4 p.s.i., resulting in vigorous sparging of the reservoirs of basal salts buffer. Cells were loaded onto a Minisart NML disposable filter $(3 \mathrm{~cm}$ diam., $0.2 \mu \mathrm{m}$ pore size; Sartorius). Prior to insertion of the sample filter, a holder with a perforated filter was substituted and basal salts buffer was drawn through the apparatus until all air was purged from the lines. A flow rate of $25 \mathrm{ml} \mathrm{h}^{-1}$ was maintained by a peristaltic pump (Microperpex S Model 2232, Pharmacia) during data collection; $0.42 \mathrm{ml}$ aliquots of the perfusate were collected in $1.5 \mathrm{ml}$ microcentrifuge tubes that were capped immediately after collection. Each microcentrifuge tube was vortexed and $350 \mu \mathrm{l}$ of the fraction was transferred to an uncapped $0.5 \mathrm{ml}$ microcentrifuge tube, which was inserted into a $6 \mathrm{ml}$ scintillation vial (Plastic sampule, Wheaton) containing $2.5 \mathrm{ml}$ Universol scintillation cocktail (ICN Biomedicals). The vials were tightly capped, stored in the dark at room temperature for $48 \mathrm{~h}$ and counted for $5 \mathrm{~min}$ in a scintillation counter (Model 3801, Beckman Instruments).

Measurement of respiration. Oxygen uptake was determined on $3 \mathrm{ml}$ of cell culture using a Clark-type oxygen electrode and oxygen monitor (Model 53, Yellow Springs Instruments) at $37^{\circ} \mathrm{C}$. The oxygen concentration of air-saturated medium was assumed to be $217 \mathrm{nmol} \mathrm{O} \mathrm{ml}^{-1}$. Protein concentration was determined using BCA (bicinchoninic acid) reagent from Pierce Chemical.

\section{RESULTS}

\section{Temporal assay of aerotaxis}

The temporal assay for aerotaxis that was used previously in studying $S$. typhimurium and E. coli (Laszlo \& Taylor, 1981) was modified for investigation of aerotaxis in $H$.

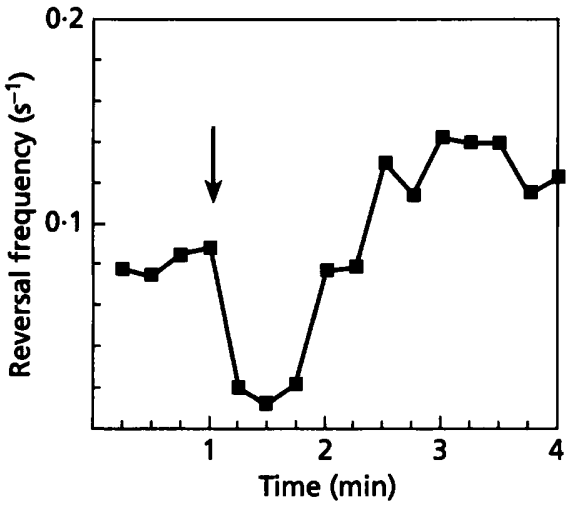

Fig. 2. Temporal assay of aerotaxis. Eight microliters of a $H$. salinarium S9-P suspension was placed in a microchamber and equilibrated with $100 \% \quad \mathrm{~N}_{2}$ gas. The ventilating gas was changed to $10 \% \mathrm{O}_{2}$ in $\mathrm{N}_{2}$ at the time indicated by the arrow. The tumbling frequency of the cells was calculated as described in Methods.

salinarium (see Methods). The swimming velocity of $H$. salinarium was enhanced by placing the apparatus in a constant temperature room at $37^{\circ} \mathrm{C}$. The speed $\left(2-5 \mu \mathrm{m} \mathrm{s}^{-1}\right)$ of $H$. salinarium cells was slower than the speed $\left(25 \mu \mathrm{m} \mathrm{s}^{-1}\right)$ of E. coli and S. typhimurium (Berg \& Brown, 1972; Macnab \& Koshland, 1972). The $H$. salinarium cells reversed direction on average once every 4-30 s, depending on the strain and growth conditions, compared to a tumbling frequency of once per second in wild-type E. coli (Spudich \& Bogomolni, 1988; Berg \& Brown, 1972). This made the timing of behavioural responses in $\mathrm{H}$. salinarium more difficult and computerized motion analysis was utilized to determine the changes in frequency of reversal of a population of $H$. salinarium during a temporal assay of aerotaxis or chemotaxis (see Methods; Lindbeck, 1991). The data obtained by motion analysis were consistent in experiments conducted on different days and were similar when analysed by different operators. Averaging over $15 \mathrm{~s}$ intervals was found to be optimal for analysis of reversal frequency.

After a brief incubation in an anoxic environment, $H$. salinarium S9-P cells gave a smooth swimming response for approximately $45 \mathrm{~s}$ when exposed to $\mathrm{O}_{2}$ (Fig. 2). This is a typical bacterial response to an attractant (Macnab \& Koshland, 1972). When aerobic $H$. salinarium was exposed to $\mathrm{N}_{2}$, there was an interval of increased reversal frequency (data not shown) that is typical of a bacterial repellent (negative) response. The magnitude of the positive (smooth swimming) aerotaxis response in $H$. salinarium varied during growth, reaching a peak when the $\mathrm{OD}_{600}$ of the culture was approximately $0 \cdot 1$ (Fig. 3 ). The peak aerotactic response coincided with a peak in respiration by the bacteria.

Temporal aerotaxis assays were performed in which the bacteria were exposed to $10 \% \mathrm{O}_{2}$ in $\mathrm{N}_{2}$ gas and then the $\mathrm{O}_{2}$ concentration in the ventilating gas was changed to $1 \%$ and returned to $10 \%$ or was changed to $100 \% \mathrm{O}_{2}$ and returned to $10 \%$. No significant behavioural responses were observed, indicating that the oxygen receptor was 


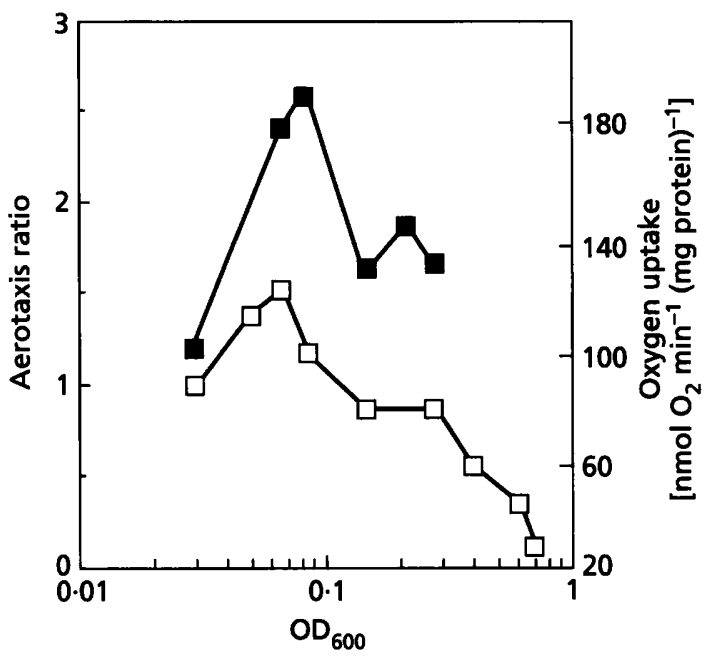

Fig. 3. Changes in aerotaxis $(\square)$ and oxygen consumption ( $\square$ ) with the growth of $\boldsymbol{H}$. salinarium S9-P. Temporal assays of aerotaxis were performed as described in the legend to Fig. 2 . The value shown is the ratio of the mean tumbling frequency during $\mathrm{N}_{2}$ ventilation and the mean tumbling frequency during exposure to $10 \% \mathrm{O}_{2}$, as determined for each aerotaxis assay.

saturated when the ventilating gas contained $1 \% \mathrm{O}_{2}$ (dissolved $\mathrm{O}_{2}$ concentration $10 \mu \mathrm{M}$ ) and that the bacteria did not exhibit an aerophobic response to $100 \% \mathrm{O}_{2}$.

\section{Aerotaxis in chemotaxis and phototaxis mutants}

Five $H$. salinarium strains (Pho5, Pho18, Pho37, Pho64 and Pho72) that are deficient in phototaxis (Pho) and chemotaxis (Che) failed to show a behavioural response to a step up or step down in oxygen concentration. However, each of the strains is smooth swimming and it is possible that the aerotaxis response is not strong enough to overcome the strong smooth swimming bias in these mutants. In a spatial aerotaxis assay, a band of the Pho72 mutant bacteria formed around an air bubble. When the band was examined at high magnification, the bacteria in the region between the bubble and the band were clearly motile, but the bacteria within the band and outside the band were immotile except for occasional sluggish 'wobbling'. As oxygen from the air bubble was depleted, the aerotactic band formed by wild-type cells moved closer to the bubble, whereas the band formed by mutant strains did not migrate toward the bubble. This is an indication that the mutant cells were trapped in a band by a loss of motility, whereas wild-type cells actively migrated to a specific oxygen concentration.

The H. salinarium Flx15 strain lacks bacteriorhodopsin and halorhodopsin, but contains the SR-I and SR-II sensory thodopsins (Sundberg et al., 1985). Cells growing in peptone medium were tested in the light at intervals for aerotaxis using an air bubble assay. At all stages of growth the $\mathrm{bR}^{-} \mathrm{hR}^{-}$cells (Flx15) formed more distinct aerotactic bands than did S9-P cells (Fig. 4). This confirmed the similar observation by Bibikov \& Skulachev (1989). During exponential growth, respiration was higher in Flx15 cells than in S9-P, which could enhance aerotaxis. However, in stationary phase cells, the respiratory rate was similar in Flx15 and S9-P but aerotaxis was much stronger in the $\mathrm{bR}^{-} \mathrm{hR}^{-}$strain.

In a further test of the role of bacteriorhodopsin in depressing aerotaxis, the formation of the aerotactic band was compared in strain $\mathrm{S} 9-\mathrm{P}\left(\mathrm{bR}^{+} \mathrm{hR}^{+}\right)$in the dark and in the light. In the dark, bacteriorhodopsin made no contribution to the proton motive force and the aerotactic band of S9-P was more distinct than it was when the cells were illuminated (data not shown). Spatial aerotaxis assays were also performed with strain Pho81 which is deficient in all four sensory thodopsins $\left(\mathrm{bR}^{-} \mathrm{hR}^{-} \mathrm{SR}-\mathrm{I}^{-} \mathrm{SR}-\mathrm{II}^{-}\right.$) (Sundberg et al., 1985). A strong aerotactic band was observed indicating that none of the rhodopsin proteins are required for aerotaxis.

\section{Effect of methylation deficiency on aerotaxis}

Ethionine and homocysteine are inhibitors of methylation that have been used to investigate the role of methylation in phototaxis and chemotaxis in H. salinarium (Schimz \& Hildebrand, 1979, 1987). The effect of ethionine and homocysteine on aerotaxis was examined using a temporal assay. Cells (S9-P) grown in peptone medium were added to an equal volume of basal salts buffer containing $20 \mathrm{mM}$ ethionine and incubated for $5 \mathrm{~h}$ before being centrifuged and resuspended in basal salts buffer and incubated for $1 \mathrm{~h}$. Ethionine treatment resulted in a $75 \%$ decrease in the tumbling frequency in the first minute after S9-P cells were exposed to oxygen. The time for the cells to adapt to the oxygen stimulus was also increased. Homocysteine $(20 \mathrm{mM})$ produced a similar increase in adaptation time for aerotaxis.

The effect of ethionine and homocysteine on the intracellular pool of $S$-adenosylmethionine in $H$. salinarium was investigated using HPLC of whole cell extracts (see Methods). Approximately $1.3 \times 10^{5}$ molecules of $S$ adenosylmethionine were present per cell $(130 \mu \mathrm{M})$. This is similar to the concentration of $S$-adenosylmethionine in S. typhimurium (Borczuk et al., 1987). Incubation of S9-P cells in defined medium that contained $20 \mathrm{mM}$ homocysteine, but not methionine, resulted in a small increase in $S$-adenosylmethionine concentration. This implies that homocysteine is converted to methionine in $H$. salinarium as it is in E. coli and S. typhimurium (Rowbury, 1983). No $S$-adenosylethionine peak was identified in cells incubated with ethionine. It is evident from these results that the interpretation of the mechanism of action of homocysteine and ethionine is not straightforward. Homocysteine probably exerts an effect on $H$. salinarium behaviour by increasing the level of $S$-adenosylhomocysteine, which competes with $S$-adenosylmethionine at the active site of the methyltransferase that is involved in chemotaxis. LEthionine partially restored chemotaxis in methioninestarved S. typhimurium (Aswad \& Koshland, 1975). The problems associated with the use of homocysteine and 

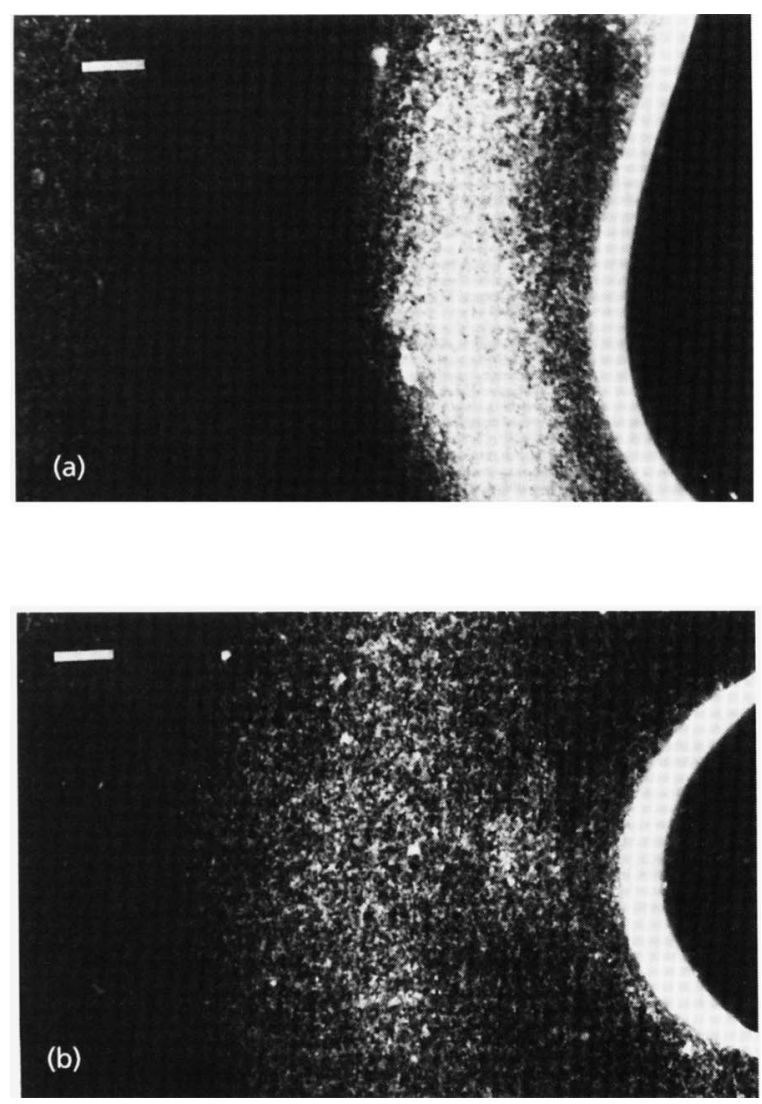

Fig. 4. Comparison of aerotaxis in (a) $H$. salinarium S9-P (wild type) and (b) strain Flx15 $\left(b R^{-} h R^{-}\right)$. Cells grown in peptone medium to an $O_{600}$ of 0.79 (S9-P) and 0.75 (F/x15) were used for a bubble assay. The photographs were taken using dark field illumination approximately $30 \mathrm{~min}$ after slide preparation. The bar represents $0.1 \mathrm{~mm}$. Oxygen uptake was $83 \mathrm{nmol} \mathrm{O}_{2} \min ^{-1}$ (mg protein) ${ }^{-1}$ (S9-P) and $130 \mathrm{nmol} \mathrm{O}_{2} \mathrm{~min}^{-1}$

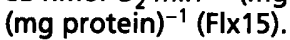

ethionine were avoided by starving for methionine to deplete the bacteria of $S$-adenosylmethionine.

H. salinarium S9-P was grown in defined medium supplemented with methionine, harvested by centrifugation and resuspended in methionine-free defined medium. After a minimum of $1 \mathrm{~h}$, the aerotaxis response of the partially starved bacteria was determined using the temporal assay. The low frequency of spontaneous reversal in the starved cells made it difficult to analyse a smooth swimming response. However, methionine starvation essentially abolished the transient increase in tumbling frequency when aerobic cells were exposed to nitrogen. These results and those obtained in the presence of ethionine and homocysteine indicated that aerotaxis in $H$. salinarium might be dependent on methylation.

\section{Autofluorography of $\left[{ }^{3} \mathrm{H}\right]$ methylated proteins}

The effect of oxygen concentration on methylation of methyl-accepting taxis proteins was examined in $H$. salinarium S9-P cells that were preincubated with [metbyl-

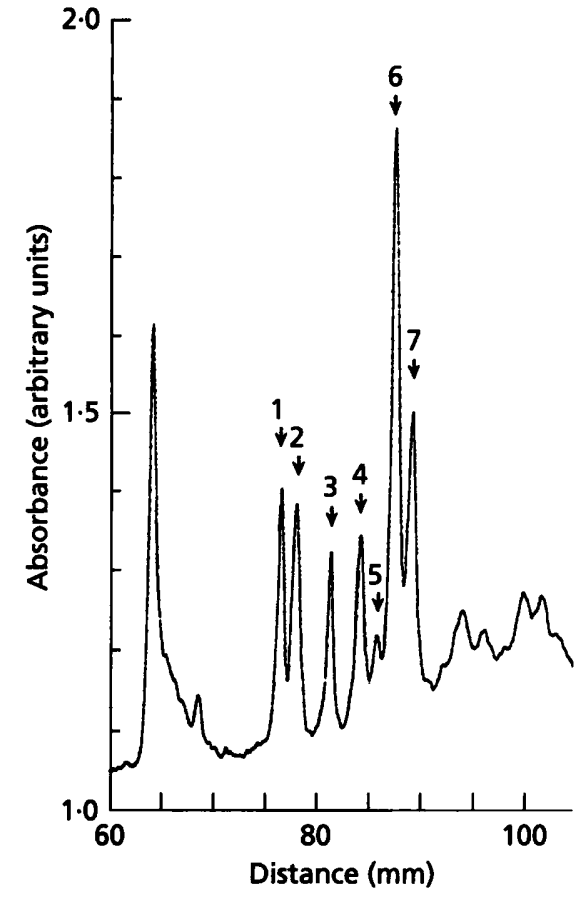

Fig. 5. Densitometric scan from an autofluorogram of ${ }^{3} \mathrm{H}$ labelled proteins from $H$. salinarium S9-P. The fluorogram was prepared and scanned as described in Methods from S9-P cells that were equilibrated with air.

$\left.{ }^{3} \mathrm{H}\right]$ methionine in the absence of protein synthesis (see Methods). Using autofluorography, the pattern of radioactivity in proteins separated by SDS-PAGE (Fig. 5) was compared for bacteria that had been preincubated under oxic and anoxic conditions. Seven radioactive bands were identified that had molecular masses between 90 and $135 \mathrm{kDa}$ (Fig. 5). This is similar to the observed methylation pattern in previous studies of chemotaxis (Alam et al., 1989; Spudich et al., 1988). No significant difference in the labelling pattern was observed when aerobic cells were exposed to $\mathrm{N}_{2}$. The time of exposure to $\mathrm{N}_{2}$ was varied to maximize the probability of observing significant changes in protein methylation. Chemoeffector-dependent changes in methylation of MCP proteins are well characterized in E. coli and S. typhimurium (Boyd \& Simon, 1980). Each additional methylation of an MCP increases the rate of migration of the protein on SDS-PAGE. However, no similar pattern of methylationdependent changes in fluorograms of methylation-dependent taxis proteins have been observed in H. salinarium in previous studies of chemotaxis (Alam et al., 1989) or in the present study. It has been proposed that in B. subtilis methyl residues may be transferred from methylationdependent taxis proteins to a carrier protein and then returned to the methylation-dependent taxis proteins (Thoelke et al., 1987). Possible relationships between the labelling of individual bands in the 90 to $135 \mathrm{kDa}$ region were investigated by quantifying the label in each of the bands and pooling the data from 16 fluorograms without regard to the experimental conditions. Scattergrams were 

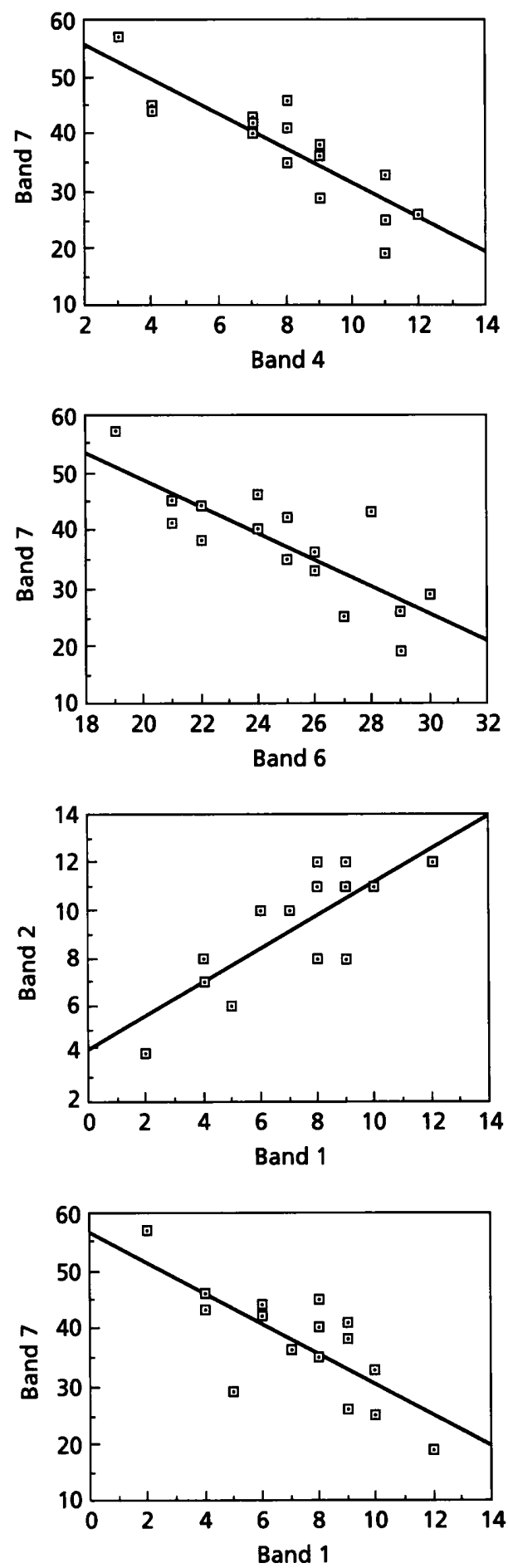

Fig. 6. Scattergram of pairwise comparison of $\left[{ }^{3} \mathrm{H}\right]$ methyl incorporation into the protein bands shown in Fig. 5 . The data were obtained by scanning autofluorograms from 16 samples analysed as described in the legend to Fig. 5. The samples varied in length of exposure to $N_{2}(0-10 \mathrm{~min})$, duration of labelling with $\left[{ }^{3} \mathrm{H}\right]$ methionine $(0.5-2 \mathrm{~h})$ and the density of the culture $\left(\mathrm{OD}_{600}=0.1\right.$ or 0.83$)$. All data were pooled without regard to the experimental conditions. The ${ }^{3} \mathrm{H}$-label incorporated into individual bands was quantified as described in Methods. A linear regression analysis was performed for each pair of bands. The results are shown for pairs of bands in which the probability was less than 0.001 in analysis of variance. constructed to determine whether changes in the extent of labelling of one peak was associated with a change in labelling of another peak (Fig. 6). If methyl label is transferred from one protein to another, the label in the former would decrease while the label in the latter would increase. The scattergrams shown are those in which the probability was less than 0.001 in the analysis of variance. An increase in the label in band 7 was associated with a decrease in labelling in bands 1, 4, and 6 .

\section{Assay of in vivo demethylation}

The flow assay of Kehry \& Dahlquist (1984) provides a sensitive assay of $\left[{ }^{3} \mathrm{H}\right]$ methanol released as a result of demethylation of methyl-accepting chemotaxis proteins during chemotaxis. Bacteria that have been labelled with $\mathrm{L}-\left[\right.$ metbyl $\left.-{ }^{3} \mathrm{H}\right]$ methionine and deposited onto a filter are perfused with medium to which chemoeffectors can be added or subtracted. The perfusate is analysed for $\left[{ }^{3} \mathrm{H}\right]$ methanol content. Novel modifications were required to adapt the apparatus for use in studying aerotaxis, including the use of tubing with very low oxygen permeability. Two reservoirs were sparged with nitrogen and oxygen, respectively. A switching valve was used to direct anoxic or oxic medium to the cells on the filter.

Oxygen addition resulted in a transient increase in methanol release by $H$. salinarium S9-P (Fig. 7a). A small increase in methanol release was sometimes observed after oxygen was withdrawn. This was independent of the order in which the cells were stimulated by changes in oxygen concentration. The magnitude of methanol release was much smaller than is observed for chemotaxis (Alam et al., 1989). This is a probable reason for the inability to detect oxygen-associated changes in the methylation of labelled proteins on polyacrylamide gels. The pattern of methanol release in chemotaxis (data not shown) was similar to that reported previously (Alam et al., 1989). No oxygen-dependent changes in volatile radioactivity were detected when the cells were labelled with $\left[{ }^{35} \mathrm{~S}\right]$ methionine, confirming that the volatile product released in response to oxygen is methanol not methanethiol (data not shown).

The aerotaxis flow assay was extremely sensitive to any oxygen that leaked into the anoxic line. An effective control for oxygen infiltration utilized two anoxic reservoirs. The cells were perfused from one of the anoxic reservoirs. After approximately $20 \mathrm{~min}$, the flow of perfusing buffer was switched to draw buffer from the other anoxic reservoir. If any oxygen had diffused into the static line, the cells responded to the oxygen by transiently increasing methanol release. The apparatus was judged to be free of significant $\mathrm{O}_{2}$ infiltration when the switch from one anoxic buffer to another did not elicit a response from the cells, Nail polish was effective in sealing valves and connections.

To determine whether the observed $\left[{ }^{3} \mathrm{H}\right]$ methanol release was the result of activity of the chemotaxis methylesterase, the flow assay was repeated using $H$. salinarium Pho72 which is deficient in methyltransferase activity and lacks normal aerotaxis. Strain Pho72 cells did not exhibit 

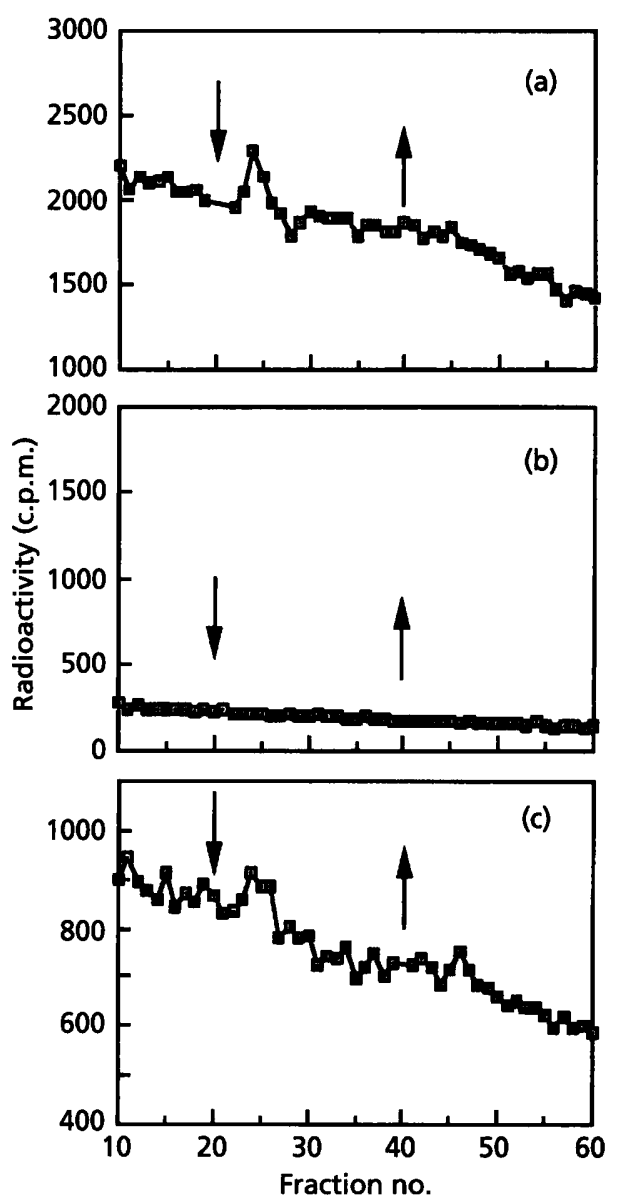

Fig. 7. $\left[{ }^{3} \mathrm{H}\right]$ Methanol production in $\mathrm{H}$. salinarium in response to changes in oxygen concentration. $\left[{ }^{3} \mathrm{H}\right]$ Methionine-labelled $H$. salinarium cells $\left(7 \times 10^{8}\right.$ cells) were loaded onto the filter in the flow assay apparatus and perfused with basal salts buffer that was equilibrated with $\mathrm{N}_{2}$ or $100 \% \mathrm{O}_{2}$. See Methods for a description of the experimental protocol. ( $\downarrow)$ indicates a switch from $\mathrm{N}_{2}$-equilibrated to $\mathrm{O}_{2}$-equilibrated buffer; $(\uparrow)$ indicates a return to $\mathrm{N}_{2}$-equilibrated buffer. (a) $H$. salinarium $\$$ 9-P, wild type for chemotaxis. (b) Strain Pho72, a mutant that is deficient in methyltransferase activity. (c) Strain Pho81, a mutant that lacks all retinal proteins $\left(b R^{-} h R^{-} S R-I^{-} S R-I^{-}\right)$.

changes in $\left[{ }^{3} \mathrm{H}\right]$ methanol release in response to changing oxygen exposure (Fig. $7 \mathrm{~b}$ ). A flow assay of the response to oxygen by strain Pho81 $\left(\mathrm{bR}^{-} \mathrm{hR}^{-} \mathrm{SR}-\mathrm{I}^{-} \mathrm{SR}-\mathrm{II}^{-}\right)$showed a peak of methanol release following oxygen addition and removal (Fig. 7c). The peaks were smaller than observed with the wild-type strain S9-P, but methanol release by strain Pho81 in response to peptone also appeared smaller than in strain S9-P (Alam et al., 1989). There was no transient change in methanol release when $E$. coli aerotaxis was studied in a flow assay (Wong et al., 1995).

\section{DISCUSSION}

An aerotaxis response in $H$. salinarium has previously been inferred from accumulation of the bacteria around an air bubble (Stoeckenius, et al., 1988; Bibikov \& Skulachev, 1989). The definitive temporal assay of taxis to oxygen in this study confirmed that finding and allowed a comparison to aerotaxis in eubacteria. The aerotactic response in $H$. salinarium showed a typical smooth swimming response to an increase in oxygen concentration (Fig. 2) and a brief tumbling interval when oxygen was removed. Aerotaxis, as measured in the temporal assay gave a $45 \mathrm{~s}$ smooth swimming response in $H$. salinarium compared to 10-15 s in E. coli or S. typhimurium (Laszlo \& Taylor, 1981) and 25-35 s in Bacillus subtilis (Wong et al., 1995).

During growth, aerotaxis was greatest in early exponential phase when $H$. salinarium had the highest respiratory capacity (Fig. 3). In the natural environment the attraction to oxygen would be strongest during times in which the bacteria were consuming the most oxygen, providing a selective advantage to wild-type $H$. salinarium over bacteria that are not aerotactic. The 'receptor' for aerotaxis in $H$. salinarium has a high affinity for oxygen and was apparently saturated by $10 \mu \mathrm{M} \mathrm{O}_{2}\left(1 \% \mathrm{O}_{2}\right)$. The bacteria were not repelled by pure oxygen in a temporal assay, although oxygen imposes an oxidative stress on bacteria. In a spatial assay the bacteria were sometimes aggregated at the meniscus and sometimes a short distance from the meniscus. In their natural habitat, $H$. salinarium would be guided to a location near the surface where oxygen is abundant. Phototaxis also assists the halobacteria in migration to an optimal environment, but the phototactic response is weaker when the ambient oxygen concentration is sufficient to support vigorous respiration (Bibikov \& Skulachev, 1989).

A release of volatile radioactivity by $H$. salinarium in response to changes in oxygen concentration was demonstrated (Fig. 7). Two volatile compounds have been detected in similar flow assays in $H$. salinarium: methanol and methanethiol (Nordmann et al., 1994). The volatile compound in this study is assumed to be methanol from hydrolysis of the carboxymethylester on methyl-accepting taxis proteins on the following basis: the volatile compound was labelled by $\left[{ }^{3} \mathrm{H}\right]$ methionine but not by $\left.{ }^{35} \mathrm{~S}\right]$ methionine, and the compound was not released by the Pho72 mutant (Fig. 7b) which lacks the methyltransferase activity that methylates the methyl-accepting taxis proteins (Sundberg et al., 1990). Methanol was released in response to an increase in oxygen concentration (Fig. 7) and a smaller peak of methanol release was seen occasionally in response to oxygen withdrawal. This is similar to the pattern of methanol release in chemotaxis and phototaxis in H. salinarium (Alam et al., 1989; Spudich et al., 1989) and also in B. subtilis (Thoelke et al., 1989), but different from the pattern of methanol release in chemotaxis in E. coli (Kehry et al., 1984). No correlation was found between exposure of $H$. salinarium to $\mathrm{O}_{2}$ or $\mathrm{N}_{2}$ and the extent of methylation of protein bands that are between 90 and $135 \mathrm{kDa}$. However, scattergrams of pairwise comparisons of ${ }^{3} \mathrm{H}$ label incorporation into the same proteins revealed some interesting comparisons that were independent of aerotaxis (Fig. 6). The label in band 7 increased as the label decreased in bands 1,4 and 6 . This pattern could be observed if band 7 accepted methyl residues from bands 1,4 and 6 , similar to a model proposed for B. subtilis (Thoelke et al., 1989). A simpler 
explanation is that bands 1, 4, 6 and 7 may be (or contain) the same protein but with an increasing number of methyl groups attached, with band 7 being the most highly methylated form of the protein. Methylation of a methylaccepting chemotaxis protein in E. coli increases the rate of migration in SDS-PAGE (Boyd \& Simon, 1980).

This is the first study to find a correlation between oxygen sensing and protein methylation, although a similar correlation has subsequently been observed in B. subtilis in this laboratory (Wong et al., 1995). Inhibition of methylation in $H$. salinarium by depletion of the methyl donor $S$-adenosylmethionine resulted in defective aerotaxis, providing further evidence of the dependence of aerotaxis on methylation in $H$. salinarium. In other bacteria that have been studied, aerotaxis is independent of methylation (Niwano \& Taylor, 1982; Taylor, 1983). This was confirmed in E. coli where the flow assay did not show any change in the rate of methanol release in response to aerotaxis (Wong, et al., 1995). Studies are in progress to identify the methyl-accepting taxis protein that is methylated in aerotaxis in $H$. salinarium and $B$. subtilis.

\section{ACKNOWLEDGEMENTS}

Strains were kindly donated by John Spudich. We thank J. Spudich, S. Sundberg, W. Stoeckenius, M. Alam and I. Zhulin for helpful discussions. This investigation was supported by Public Health Service Grant GM 29481 from the National Institute of General Medical Sciences.

\section{REFERENCES}

Alam, M. \& Hazelbauer, G. L. (1991). Structural features of methylaccepting taxis proteins conserved between archaebacteria and eubacteria revealed by antigenic cross-reaction. $J$ Bacteriol 173, $5837-5842$.

Alam, M. \& Oesterhelt, D. (1984). Morphology, function and isolation of halobacterial flagella. $J$ Mol Biol 176, 459-475.

Alam, M., Lebert, M., Oesterhelt, D. \& Hazelbauer, G. L. (1989). Methyl-accepting taxis proteins in Halobacterium balobium. EMBO J 8, 631-639.

Armitage, J. P. (1993). Methylation-independent behavioral responses in bacteria. In Signal Transduction. Prokaryotic and Simple Eukaryotic Systems, pp. 43-65. Edited by J. Kurjan \& B. L. Taylor. San Diego: Academic Press.

Aswad, D. W. \& Koshland, D. E., Jr (1975). Evidence for an $S$ adenosylmethionine requirement in the chemotactic behavior of Salmonella typhimurium. J Mol Biol 97, 207-223.

Berg, H. C. \& Brown, D. A. (1972). Chemotaxis in Escherichia coli analyzed by three-dimensional tracking. Nature 239, 500-504.

Bibikov, S. I. \& Skulachev, V. P. (1989). Mechanisms of phototaxis and aerotaxis in Halobacterium balobium. FEBS Lett 243, 303-306.

Bibikov, S. L., Grishanin, R. N., Marwan, W., Oesterhelt, D. \& Skulachev, V. P. (1991). The proton pump bacteriorhodopsin is a photoreceptor for signal transduction in Halobacterium balobium. FEBS Lett 295, 223-226.

Bibikov, S. L., Grishanin, R. N., Kaulen, A. D., Marwan, W., Oesterhelt, D. \& Skulachev, V. P. (1993). Bacteriorhodopsin is involved in halobacterial photoreception. Proc Natl Acad Sci US A 90, 9446-9450.
Borczuk, A., Stock, A. \& Stock, J. (1987). S-Adenosylimethionine may not be essential for signal transduction during bacterial chemotaxis. J Bacteriol 169, 3295-3300.

Bourret, R. B., Borkovich, K. A. \& Simon, M. I. (1991). Signal transduction pathways involving protein phosphorylation in prokaryotes. Annu Rev Biochem 60, 401-441.

Boyd, A. \& Simon, M. I. (1980). Multiple electrophoretic forms of methyl-accepting chemotaxis proteins generated by stimulus elicited methylation in Escherichia coli. J Bacteriol 143, 809-815.

Carpenter, P. B., Hanlon, D. W., Kirsch, M. L. \& Ordal, G. W. (1994). Novel aspects of chemotactic sensory transduction in Bacillus subtilis. Res Microbiol 145, 413-419.

Grey, V. L. \& Fitt, P. S. (1976). An improved synthetic growth medium for Halobacterium cutirubrum. Can J Microbiol 122, 440-442.

Johnson, M. S. \& Taylor, B. L. (1993). Comparison of methods for specific depletion of ATP in Salmonella typhimurium. Appl Environ Microbiol 59, 3509-3512.

Kehry, M. R., Doak, T. G. \& Dahiquist, F. W. (1984). Stimulusinduced changes in methylesterase activity during chemotaxis in Escherichia coli. J Biol Chem 259, 11828-11835.

Krah, M., Marwan, W., Vermegilo, A. \& Oesterhelt, D. (1994). Phototaxis of Halobacterium salinarium requires a signalling complex of sensory rhodopsin I and its methyl-accepting transducer HtrI. EMBO J 13, 2150-2155.

Laemmli, U. K. (1970). Cleavage of structural proteins during the assembly of the head of bacteriophage T4. Nature 227, 680-685.

Lanyi, J. K. \& MacDonald, R. E. (1979). Light-induced transport in Halobacterium halobium. Methods Enzymol 56, 398-407.

Laszlo, D. J. \& Taylor, B. L. (1981). Aerotaxis in Salmonella typhimurium: role of electron transport. J Bacteriol 145, 990-1001.

Lindbeck, J. C. (1991). Aerotaxis in Halobacterium halobium. $\mathrm{PhD}$ thesis. Loma Linda University, Loma Linda, California, USA.

Lindbeck, J. C., Goubourne, E. A., Jr \& Taylor, B. L. (1990). Aerotaxis of Halobacterium balobium. Abstracts of the 90th Annual Meeting of the American Society for Microbiology 1990. Abstract I-72, p. 210.

McCleary, W. R. \& Stock, J. B. (1993). Phosphorylation in bacterial chemotaxis. In Signal Transduction. Prokaryotic and Simple Eukaryotic Systems, pp. 17-41. Edited by J. Kurjan \& B. L. Taylor. San Diego: Academic Press.

Macnab, R. M. (1992). Genetics and biogenesis of bacterial flagella. Annu Rev Genet 26, 131-158.

Macnab, R. M. \& Koshland, D. E., Jr (1972). The gradient-sensing mechanism in bacterial chemotaxis. Proc Natl Acad Sci USA 69, 2509-2512.

Niwano, M. \& Taylor, B. L. (1982). Novel sensory adaptation mechanism in bacterial chemotaxis to oxygen and phosphotransferase substrates. Proc Natl Acad Sci USA 79, 11-15.

Nordmann, B., Lebert, M. R., Alam, M., Nitz, S., Kollmannsberger, H., Oesterhelt, D. \& Hazelbauer, G. (1994). Identification of volatile forms of methyl groups released by Halobacterium salinarium. J Biol Chem 269, 16449-16454.

Rowbury, R. J. (1983). Methionine biosynthesis and its regulation. In Amino Acids: Biosynthesis and Genetic Regulation, pp. 191-211. Edited by K. M. Herrmann \& R. L. Somerville. Reading, MA: Addison-Wesley Publishing Co.

Sager, B. M., Sekelsky, J. J., Matsumura, P. \& Adler, J. (1988). Use of a computer to assay motility in bacteria. Anal Biochem 173, 271-277. 
Schimz, A. \& Hildebrand, E. (1979). Chemosensory responses of Halobacterium balobium. J Bacteriol 140, 749-753.

Schimz, A. \& Hildebrand, E. (1987). Effects of cGMP, calcium and reversible methylation on sensory signal processing in halobacteria. Biochim Biophys Acta 923, 222-232.

Shioi, J. \& Taylor, B. L. (1984). Oxygen taxis and proton motive force in Salmonella typhimurium. J Biol Chem 259, 10983-10988.

Shioi, J. C., Dang, V. \& Taylor, B. L. (1987). Oxygen as attractant and repellent in bacterial chemotaxis. J Bacteriol 169, 3118-3123.

Shioi, J. C., Tribhuwan, R. C., Berg, S. T. \& Taylor, B. L. (1988). Signal transduction in chemotaxis to oxygen in Eschericbia coli and Salmonella typhimurium. J Bacteriol 170, 5507-5511.

Spudich, J. L. \& Bogomolni, R. A. (1988). Sensory rhodopsins of halobacteria. Annu Rev Biopbys Chem 17, 193-215.

Spudich, E. N. \& Spudich, J. L. (1982). Control of transmembrane ion fluxes to select halorhodopsin-deficient and other energytransduction mutants of Halobacterium halobium. Proc Natl Acad Sci US $A$ 79, 4308-4312.

Spudich, E. N. \& Spudich, J. L. (1993). The photochemical reactions of sensory rhodopsin I are altered by its transducer. J Biol Chem 268, 16095-16097.

Spudich, E. N., Hasselbacher, C. A. \& Spudich, J. L. (1988). Methylaccepting protein associated with bacterial sensory rhodopsin I. $J$ Bacteriol 170, 4280-4285.

Spudich, E. N., Takahashi, T. \& Spudich, J. L. (1989). Sensory rhodopsin I and II modulate a methylation/demethylation system in Halobacterium balobium phototaxis. Proc Natl Acad Sci US A 86, 7746-7750.

Stoeckenius, W., Wolff, E. K. \& Hess, B. (1988). A rapid population method for action spectra applied to Halobacterium balobium. $J$ Bacteriol 170, 2790-2795.

Sundberg, S. A., Bogomolni, R. A. \& Spudich, J. L. (1985). Selection and properties of phototaxis-deficient mutants of Halobacterium balobium. J Bacteriol 164, 282-287.
Sundberg, S. A., Alam, M. \& Spudich, J. L. (1986). Excitation signal processing times in Halobacterium balobium phototaxis. Biophys J 50, 895-890.

Sundberg, S. A., Alam, M., Lebert, M., Spudich, J. L., Oesterhelt, D. \& Hazelbauer, G. (1990). Characterization of Halobacterium balobium mutants defective in taxis. J Bacteriol 172, 2328-2335.

Taylor, B. L. (1983). Role of proton motive force in sensory transduction in bacteria. Annu Rev Microbiol 37, 551-573.

Taylor, B. L. \& Johnson, M. S. (1993). Universal themes of signal transduction in bacteria. In Signal Transduction. Prokaryotic and Simple Eukaryotic Systems, pp. 3-15. Edited by J. Kurjan \& B. L. Taylor. San Diego: Academic Press.

Thoelke, M. S., Bedale, W. A., Nettleton, D. O. \& Ordal, G. W. (1987). Evidence for an intermediate methyl-acceptor for chemotaxis in Bacillus subtilis. J Biol Chem 262, 2811-2816.

Thoelke, M. S., Kirby, J. R. \& Ordal, G. W. (1989). Novel methyl transfer during chemotaxis in Bacillus subtilis. Biochemistry 28, 5585-5589.

Weber, K. \& Osborn, M. (1969). The reliability of molecular weight determinations by dodecyl sulfate-polyacrylamide gel electrophoresis. J Biol Chem 244, 4406-4412.

Wong, L. S., Johnson, M. S., Zhulin, I. B. \& Taylor, B. L. (1995). Role of methylation in aerotaxis in Bacillus subtilis. J Bacteriol 177, 3985-3991.

Yan, B., Cline, S. W., Doolitle, W. F. \& Spudich, J. L. (1992). Transformation of a Bop- Hop- Sop- $\mathrm{I}^{-}$Sop-II' Halobacterium balobium mutant to $\mathrm{Bop}^{+}$: effects of bacteriorhodopsin photoactivation on cellular proton fluxes and swimming behavior. Photochem Photobiol 56, 553-561.

Yao, V.J. \& Spudich, J. L. (1992). Primary structure of an archaebacterial transducer, a methyl-accepting protein associated with sensory rhodopsin I. Proc Natl Acad Sci US A 89, 11915-11919.

Received 6 March 1995; revised 28 June 1995; accepted 5 July 1995. 